A consistent pattern emerges with all these new journals. They are justified (usually defensively) by their editors on the grounds of bringing a subject together and/or accelerating publication. None have page charges, a wise decision for such new-born infants, and all are supported by an editorial board or advisory panel of well-established marine biologists (JPR 36; MBL 20; MEPS about 100; MER 12) who referee papers or channel them in the appropriate direction. This commitment by the publishers appears to be openended, except for MEPS, which has appointed a very large advisory board for a specified time of four years. These editorial boards undoubtedly give the journals an immediate respectability but the real criterion of commitment by the board is the extent to which its members use the journal themselves. A quick check through the journal numbers available to me shows no great evidence for this:

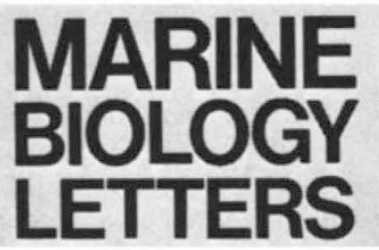

Nonetheless the publishers have commissioned experienced and distinguished editors (or have these editors persuaded the publishers to start a new series?) and there is no reason to suppose that all the journals will not be more-or-less successful. The output of volumes seems to be going quite well and there is no immediate prognosis for an early larval mortality. The journals will perhaps be especially attractive to scientists in North America where page charges are becoming increasingly the norm; in this context, it may be significant that in the four numbers of MER supplied for review 19 of the 24 papers are by authors from the USA.

There are some overlaps between the new journals and ones of longer standing; for example, MEPS with Marine Biology; MBL with Marine Behaviour and Physiology and Comparative Biochemistry and Physiology; MER with Environmental Pollution and Estuarine, Coastal and Shelf Marine Science. JPR may have the best claim to fulfil a new role, providing a real focus for plankton papers; but, we must ask ourselves, will a Journal of Benthos Research come next?

Together with Marine Ecology, a continuation of Pubblicazione della Stazione Zoological di Napoli (not reviewed here), these new arrivals represent a substantial increase in publishing space for marine biologists. Whether this will help to raise the average standard of papers is questionable, but at the least it will certainly alleviate recent delays in publication.

J.H.S. Blaxter is Senior Principal Scientific Officer at the Dunstaffnage Marine Research Laboratory of the Scottish Marine Biological Association, Oban, Scotland.

\title{
Parasitology for Specialists
}

\section{F.E.G. Cox}

Molecular and Biochemical Parasitology. Managing editors M. Müller et al. 12/yr in 2 vols. (Elsevier/North-Holland Biomedical.) Dfl.404. Parasite Immunology. Editors R.J. Terry and G.A.T. Targett. 6/yr. (Blackwell Scientific.) $£ 60$ UK, \$165 US, £72 elsewhere. Systematic Parasitology. Editor Sheila Willmott. 4/yr. (Dr W. Junk.) DG 75 (personal); DG 150 (institutional).

WELI. over 20 internationally recognized journals are devoted almost entirely to parasitology and papers on various aspects of this subject appear in virtually every journal concerned with animal biology or medicine. The justification for the publication of these three new journals is not only that there has been a disproportionately large increase in the amount of work being carried out in this field (much of it generated directly or indirectly by the WHO), but that much of the research is being done by scientists attracted to parasitology from other disciplines who have sought outlets for their discoveries in both parasitological and non-parasitological journals. This has led to problems because the traditional parasitological journals have been reluctant to accept papers in which the emphasis has been largely, for example, biochemical and, similarly, the more traditional specialized journals have tended to reject papers on the grounds that their contents were more suitable for a parasitological journal. These three new journals represent successful attempts to fill important gaps and to act as bridges between disciplines.

The aim of Molecular and Biochemical Parasitology (MBP) is to publish papers on the molecular biology and biochemistry of parasites and their interactions with the host, and the ten major subject areas covered are actually laid down. Each issue contains relatively short (about 10-15 pages) succinct papers that appear to be pared down to essential details. The coverage has been fairly wide with the emphasis on the parasites themselves rather than on host-parasite interactions; however the editors acknowledge this restriction and intend to broaden the scope of the journal. In general, most papers are concerned with the better-known parasites so are likely to be of interest to a wide audience. MBP has published contributions from wellestablished scientists and laboratories and has already had to issue an extra volume. Most papers appear within 9-12 months of receipt.

Parasite Immunology (PI) is intended to cover all aspects of the immunology of parasites in the most general sense including bacteria, viruses, fungi and ectoparasites - but most of the papers so far published have been concerned with the better known protozoa and helminths. The papers are relatively short (about 10 pages), and well written and edited so that they are comprehensible to both parasitologists and immunologists, and mainly emanate from the better known laboratories and scientists The editors promise to publish reviews but so far only one has appeared. My only criticism of PI is the long delay between acceptance and publication (8-14 months) which is far too long in such a rapidly moving field, but this should improve when the present four issues are increased to six a year in 1982 .

The scope of Systematic Parasitology (SP) is the systematics of all groups of parasites, and the journal publishes "normal" papers (up to 6,000 words), major reviews and brief notes. All three kinds of contribution have appeared and most have been concerned with nematodes and have tended to reflect a classical morphological approach to systematics. SP is attractively printed in a large format with clear illustrations, and papers appear within 8-9 months of acceptance.

All three journals fill important gaps, all are well-produced, conventional publications printed on glossy paper with excellent reproduction of photographs and line drawings, and all have attracted papers on interesting topics from established scientists. Without these journals most of these papers would have been published elsewhere but would probably have been written in different ways and some might well have become lost in journals not widely consulted by the majority of parasitologists. All represent good value for money; librarians will not be pleased to hear that they should be taken by any institution concerned with parasitology. $\square]$

F.E.G. Cox is Professor of Zoology at King's College, University of London.

\section{Experimental Botany}

\section{James F. Sutcliffe}

Plant, Cell and Environment. Editor $\mathrm{H}$. Smith. 6/yr. (Blackwell Scientific.) $£ 95$ UK, \$245 US, $£ 114$ elsewhere. Photosynthesis Research. Editor-in-chief R. Marcelle. 4/yr. (DrW. Junk.) DG70 (personal); DG 140 (institutional.) Photobiochemistry and Photobiophysics. Managing editor $\mathrm{H}$. Metzner. 6/yr. (Elsevier/North-Holland Biomedical.) Df1.202. Journal of Plant Nutrition. Editor J.B. Jones. 12/yr. (Dekker.) $\$ 175$.

PlANT physiologists are fortunate in having a wide choice of journals. Apart from the long-established general botanical periodicals such as Annals of Botany and The Botanical Gazette which, 